\title{
Article \\ A Study of the Residual Strength of Reactive Powder-Based Geopolymer Concrete under Elevated Temperatures
}

\author{
Thathsarani Kannangara *, Maurice Guerrieri, Sam Fragomeni and Paul Joseph (D) \\ Institute for Sustainable Industries and Liveable Cities, Victoria University, P.O. Box 14428, \\ Melbourne, VIC 8001, Australia; Maurice.Guerrieri@vu.edu.au (M.G.); sam.fragomeni@vu.edu.au (S.F.); \\ Paul.Joseph@vu.edu.au (P.J.) \\ * Correspondence: a.kannangara@live.vu.edu.au
}

Citation: Kannangara, T.; Guerrieri, M.; Fragomeni, S.; Joseph, P. A Study of the Residual Strength of Reactive Powder-Based Geopolymer Concrete under Elevated Temperatures. Appl. Sci. 2021, 11, 11834. https://doi.org/ 10.3390/app112411834

Academic Editor: Luis Laim

Received: 10 November 2021 Accepted: 10 December 2021 Published: 13 December 2021

Publisher's Note: MDPI stays neutra with regard to jurisdictional claims in published maps and institutional affiliations.

Copyright: (c) 2021 by the authors. Licensee MDPI, Basel, Switzerland. This article is an open access article distributed under the terms and conditions of the Creative Commons Attribution (CC BY) license (https:// creativecommons.org/licenses/by/ $4.0 /)$.

\begin{abstract}
This paper reports on studies relating to the unstressed residual compressive strengths of geopolymer pastes that are heated up to $800^{\circ} \mathrm{C}$, behavior of reactive powder concrete before and after exposure to elevated temperatures and thermal behavior of novel reactive powder geopolymer-based concretes. For this purpose, 10 geopolymer pastes and three reactive powder concrete mixtures were tested for residual strengths. Gladstone fly ash was used as the primary binder for both geopolymer pastes and reactive powder geopolymer concretes. In addition, four novel reactive powder geopolymer concrete mixes were prepared with zero cement utilization. While reactive powder concretes achieved the highest seven-day compressive strengths of approximately $140 \mathrm{MPa}$, very poor thermal behavior was observed, with explosive spalling occurring at a temperature of ca. $360{ }^{\circ} \mathrm{C}$. The reactive powder geopolymer concretes, on the other hand, displayed relatively high thermal properties with no thermal cracking at $400{ }^{\circ} \mathrm{C}$, or visible signs of spalling and very mild cracking in one case at $800{ }^{\circ} \mathrm{C}$. In terms of the strength of reactive powder geopolymer concrete, a maximum compressive strength of approximately $76 \mathrm{MPa}$ and residual strengths of approximately $61 \mathrm{MPa}$ and $51 \mathrm{MPa}$ at $400{ }^{\circ} \mathrm{C}$ and $800{ }^{\circ} \mathrm{C}$, respectively, were observed.
\end{abstract}

Keywords: geopolymer; reactive powder; elevated temperatures; residual strength; spalling

\section{Introduction}

Owing to the increasing number of high fire risk infrastructures built around the world, including concrete tunnels, petrochemical plants, nuclear reactors, and oil refineries, concrete structures with a relatively high strength capacity and superior fire resistance are in high demand. Reactive powder concretes (RPC) were first developed in the early 1990s by a French Corporation [1]. They are currently used as an ultra-high performance concrete, where compressive strengths in the range of 150-800 $\mathrm{MPa}$, tensile strengths between 6-13 MPa, flexural strengths in the range of 30-60 MPa and fracture energy in the range of $1200-40,000 \mathrm{~J} / \mathrm{m}^{2}$ can be achieved [1-4]. Related studies also reported that further enhancements in mechanical properties can be achieved through the reduction in the water to cement $(\mathrm{w} / \mathrm{c})$ ratio, exclusion of large aggregate particles, decrements in the calcium oxide to silicon dioxide ratio and through the addition of steel fibres as the reinforcement agent $[5,6]$.

Typical dry ingredients of RPC include cement, as the binding material, together with silica fumes, an ultra-fine spherical shaped material, having an average diameter of about $0.15 \mu \mathrm{m}$ and aggregate fillers, such as silica flour and fine sand/quartz particles, typically less than $600 \mu \mathrm{m}$ in size [3,6]. The w/c ratio of RPC is reported to be between $0.1-0.25$, whereas conventional concretes consist of a w/c ratio between 0.35-0.7 [6]. Superplasticizers (SP), which reduces the use of water whilst obtaining the required workability conditions, is considered as another key ingredient. A study on the influence of naphthalene, melamine and acrylic polymer superplasticizers on the strength and $\mathrm{w} / \mathrm{c}$ ratio of RPC found that the incorporation of acrylic polymer superplasticizer generally required 
a low $\mathrm{w} / \mathrm{c}$ ratio [7]. Furthermore, specimens having the acrylic polymer superplasticizer recorded higher compressive strengths compared to the specimens that incorporated either of the other two ingredients.

In spite of its higher performance in terms of strength, RPCs behave very poorly in fire scenarios, where it often undergoes spalling, which is associated with the breaking away of concrete layers, thus causing degradation and loss of mechanical properties of the base matrix [8-12]. The compressive strength, tensile strength and fracture energy of RPCs when exposed to temperatures of up to $600^{\circ} \mathrm{C}$ was investigated, where significant levels of spalling were also found to occur [8]. In addition, after being exposed to temperatures of $400{ }^{\circ} \mathrm{C}$, the compressive strength was found to decrease significantly. It was also reported that the temperature range of $400-600{ }^{\circ} \mathrm{C}$ is the critical temperature range for spalling. When some similar properties were tested [11], the residual strength was found to vary, where it was found to decrease up to $100{ }^{\circ} \mathrm{C}$, then increased over a temperature range of $200-500{ }^{\circ} \mathrm{C}$ and finally was observed to decrease above $600{ }^{\circ} \mathrm{C}$. In addition, explosive spalling conditions were also found to occur during a temperature range of $260-520^{\circ} \mathrm{C}$.

On the other hand, geopolymer (GP) concretes, which is a mixture of a material(s) rich in silica and alumina, an alkaline liquid (most commonly a combination of sodium hydroxide, or potassium hydroxide and sodium silicate, or potassium silicate) and aggregate particles [13], have been reported to possess similar, if not better, performance as compared to conventional ordinary Portland cement (OPC)-based concretes, especially when exposed to heat/fire [14]. Reports also showed that GPs possess a relatively higher fire resistance owing to its ceramic-like properties and that GP composites are ideally suited for construction, transportation and infrastructure, where fire endurance is part of the requirements $[15,16]$. In addition to this, GP concretes were found to achieve high compressive strengths within $24 \mathrm{~h}$ of conditioning, provided an ease of workability and controllable setting times, possessed good abrasion resistance, superior resistance to alkali environments and exhibited low shrinkage and low thermal conductivity and high corrosion resistance for the steel reinforcement elements [17-21].

Türkmen et al. [22] investigated the residual compressive strength performance of $50 \mathrm{~mm}$ GP concrete cube specimens, having initial strengths of approximately 35 and $32 \mathrm{MPa}$, after being exposed to temperatures up to $700{ }^{\circ} \mathrm{C}$. The average value over triplicate runs indicated that between $100-300{ }^{\circ} \mathrm{C}$ the maximum compressive strength was reached, which can be attributed to the promotion of polycondensation between chainstructures thus forming GP gels. In addition, between $300{ }^{\circ} \mathrm{C}$ to $700{ }^{\circ} \mathrm{C}$, the residual compressive strength had deteriorated which can be assumed to occur owing to the thermal incompatibility between the paste and aggregate and also due to the fracture cracking brought about by the buildup of in situ pore pressures [22]. Sarker et al. [23] found that GP concrete cylinders have generally a higher conductivity than OPC concrete, owing in part to their relatively higher content of metal ions, such as, aluminum and iron. For these specimens, no spalling was found to occur and the ones with initial compressive strengths of $39-58 \mathrm{MPa}$ had residual compressive strengths in the order of $83-59 \%$ at $650{ }^{\circ} \mathrm{C}, 27-29 \%$ at $800{ }^{\circ} \mathrm{C}$ and $16-18 \%$ at $1000{ }^{\circ} \mathrm{C}$, respectively. The loss in strength was attributed to cracking and analysis by Scanning Electron Microscopy (SEM) confirmed that the GP matrix became denser at elevated temperatures, which might have provided the enhanced resistance to spalling.

Kong and Sanjayan [24] investigated the structural damage occurring to GP composites when exposed to elevated temperature. After exposure to $80{ }^{\circ} \mathrm{C}$, GP paste gained $53 \%$ in strength, whilst the GP/aggregate composite had a strength reduction $63 \%$. This is assumed to be due to the thermal incompatibility between GP binder and aggregate, which was subsequently proved by diametric measurements of GP and aggregate [25]. Kong et al. [26] concluded that the high permeability of the GP matrix allowed the moisture to escape, which in turn reduced the buildup of pore water pressures and the tendency of spalling to occur. 
While GP concretes exhibit high resistance to elevated temperature levels, the high strengths achieved by RPCs cannot be generally matched. In addition to the relatively poor fire resistance of RPCs, they are also classified as materials that have a high carbon footprint, thus could result in additional adverse effects on the environment. In a study which tested the compressive strength of RPCs, where the binding material was replaced with FA and slag [27], a definite increase in the readings were reported in comparison to cement-based RPC, where all specimens achieved compressive strengths of over $200 \mathrm{MPa}$. In a similar study [28], the effects of using FA and slag as alternative materials for RPC production were investigated. At optimum proportions of the constituents of the mix design, the compressive strength reached up to $281 \mathrm{MPa}$. In a related study, it was also revealed that a combined RPC and GP concrete will contribute considerably to sustainable development, while lowering environmental impact and concomitantly providing efficient structural performance [29]. Obviously, a thorough comparative study of these two materials, especially at elevated temperature levels is highly desirable.

Despite several studies were conducted on GP and RPC, research regarding the behaviour of a combination of RPC and GP under fire-related scenarios is rather limited. Therefore, the novelty of the current work directly stems from the fact that it encompasses an extensive experimental program on Fly Ash (FA)-based GP pastes, RPC and a combined FA-based RPC and activated using sodium-based alkaline solutions-called Reactive Powder Geopolymer Concrete (RPGC). Factors such as characteristic strength, workability, conditioning parameters, production methods along with the residual strength, thermal cracking and weight loss parameters at elevated temperatures were investigated, through a series of controlled laboratory tests.

\section{Materials and Methods}

This section describes the experimental procedures carried out for the current study, including, materials, sample preparation, mixing and conditioning and testing of cubical samples. Parameters such a density, workability, compressive strength before and after exposure to elevated temperatures and weight losses were also measured. All the tests were conducted under laboratory conditions. Here we have also observed that the results obtained, typically over triplicate measurements, were reasonably precise. Hence the averages are quoted in the respective tables and the standard deviations are shown in the graphical representations.

\subsection{Materials}

\subsubsection{Geopolymer (GP)-Based Pastes}

The fly ash (FA) utilized in this investigation was obtained from Gladstone power station in Queensland, Australia (Class F- low calcium FA: ASTM C618 [30]. The chemical composition, obtained X-Ray Fluorescence (XRF) analysis and as reported by the manufacturer, is shown in Table 1 . The various physical properties of FA, such as, particle size distribution, mean particle diameter, specific surface area, average pore diameter and pore volume are also given.

The information regarding the particle size distribution and average diameter were also available from the supplier-these parameters were measured by using a CILAS Particle Size Analyzer 1190. The particle shape analyses were performed by using a Zeiss Supra 40 VP Scanning Electron Microscope (SEM); however, the actual SEM images were not made available owing to commercial sensitivity. The samples were thinly gold coated with a DYNAVAC (CS 300) deposition system prior to the SEM analysis. The specific surface area and pore properties of FA were based on the nitrogen adsorption method, by using Belsorp Max equipment (i.e., by using Brunauer-Emmett-Teller (BET) theoryBELMasterTM Version 6.3.1.0 software, which was developed by BEL Japan, Inc., Osaka, Japan) [31]. Here, the amount of adsorbed gas to a monomolecular layer on the surface corresponds to a specific surface area and pore volume value. 
Table 1. Chemical compositions of FA.

\begin{tabular}{cc}
\hline Compound & Oxide (wt. \%) \\
\hline $\mathrm{SiO}_{2}$ & 51.1 \\
$\mathrm{Al}_{2} \mathrm{O}_{3}$ & 25.6 \\
$\mathrm{Fe}_{2} \mathrm{O}_{3}$ & 12.5 \\
$\mathrm{CaO}$ & 4.30 \\
$\mathrm{~K}_{2} \mathrm{O}$ & 0.70 \\
$\mathrm{MgO}$ & 1.45 \\
$\mathrm{Na}_{2} \mathrm{O}$ & 0.77 \\
$\mathrm{TiO}_{2}$ & 1.32 \\
$\mathrm{BaO}^{\mathrm{SO}}$ & 0.09 \\
$\mathrm{P}_{2} \mathrm{O}_{5}$ & 0.24 \\
$\mathrm{MnO}$ & 0.89 \\
Volatile fraction & 0.15 \\
\hline
\end{tabular}

Figure 1 shows the particle size distribution for the Gladstone based fly ash. The density of the sample was determined to be $2.29 \mathrm{~g} / \mathrm{cm}^{3}$. The largest particle diameter measured for Gladstone fly ash was $100 \mu \mathrm{m}$, with $50 \%$ of Gladstone fly ash particle size ranging from $1 \mu \mathrm{m}$ to $100 \mu \mathrm{m}$ and $50 \%$ are under $1 \mu \mathrm{m}$ in size. The pore volume was determined to be $3.39 \mathrm{~mm}^{3} / \mathrm{g}$ and the mean pore diameter was $11.8 \mathrm{~nm}$. The specific surface area of the Gladstone fly ash was $1.15 \mathrm{~m}^{2} / \mathrm{g}$ which was in agreement with previously reported results [32].

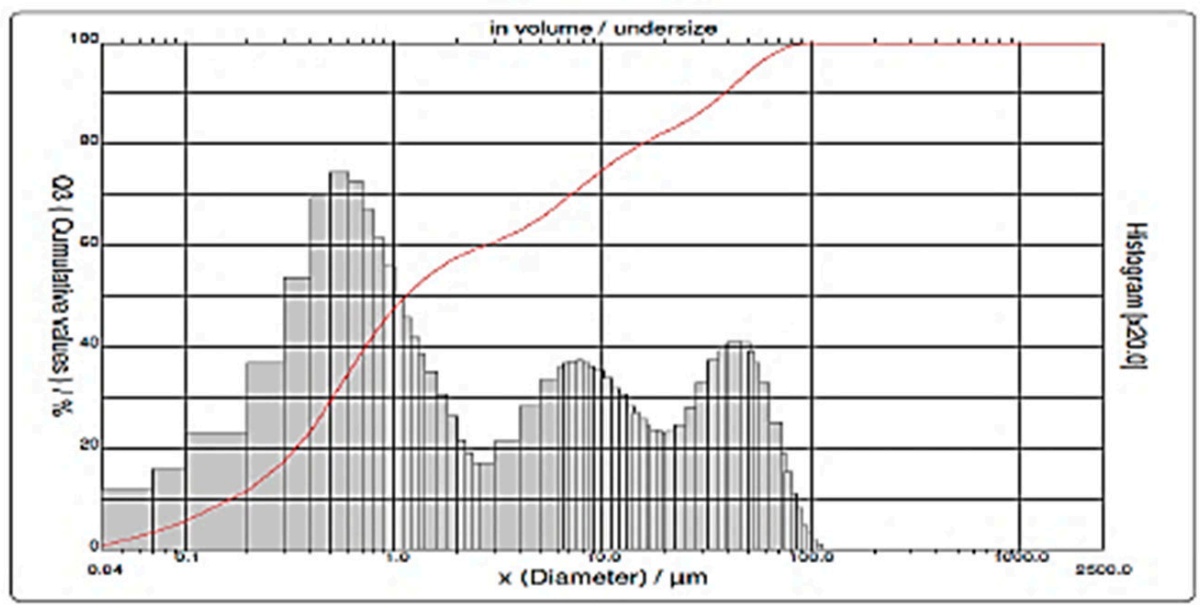

Figure 1. The aggregate particle size distribution graph for Gladstone FA.

The alkaline activator that was employed constituted of Grade D sodium silicate (ratio of $\mathrm{SiO}_{2}$ to $\mathrm{Na}_{2} \mathrm{O}$ is 1:2 by weight) and $8.0 \mathrm{M}$ sodium hydroxide, $\mathrm{NaOH}$. The sodium hydroxide solution consisted of $26.2 \mathrm{wt}$. \% of $\mathrm{NaOH}$ solids and $73.8 \mathrm{wt}$. \% of water [33]. A total of 10 alkaline activator combinations were investigated in this study and they consisted of varying the ratio of $\mathrm{Na}_{2} \mathrm{SiO}_{3} / \mathrm{NaOH}$, from 0.5, 1.0, 1.5, 2.0 and 2.5 and at two alkaline solution to FA ratios of 0.4 and 0.57 . These combinations are referred in the text as GP 01, GP 02 etc., as summarized in Table 2, which also presents the complete mix design proportions in each case.

Sodium hydroxide and sodium silicate were first measured and mixed using a handheld stirrer bar until a clear, transparent solution was formed (ca. $2 \mathrm{~min}$ ). The mixture was then kept aside to rest for 3 min before being mixed with the FA. This method was essentially adopted from a previously published work by Hardjito and Rangan [34]. Subsequently, the FA was measured and mixed with the liquid solution, using a Breville mixer at a working speed of 50 revolutions per minute (rpm) for $2 \mathrm{~min}$ and then for another $3 \mathrm{~min}$ at a working speed of $85 \mathrm{rpm}$, after which, $25 \mathrm{~mm}^{3}$ specimens were casted. 
Table 2. GP paste mix design.

\begin{tabular}{|c|c|c|c|c|}
\hline Sample ID & $\begin{array}{c}\text { Sample Composition for } \\
1 \text { kg of FA- (Alkaline } \\
\text { Solution/FA Ratio; } \\
\mathrm{Na}_{2} \mathrm{SiO}_{3} / \mathrm{NaOH} \text { ) }\end{array}$ & $\begin{array}{l}\text { Sodium Silicate } \\
\text { Grade D (kg) }\end{array}$ & $\begin{array}{c}8 \mathrm{M} \mathrm{NaOH} \\
(\mathrm{kg})\end{array}$ & $\begin{array}{c}\text { Total Weight } \\
\text { (kg) }\end{array}$ \\
\hline GP 01 & GP- $0.40 ; 0.50$ & 0.133 & 0.267 & 1.40 \\
\hline GP 02 & GP- $0.40 ; 1.00$ & 0.200 & 0.200 & 1.40 \\
\hline GP 03 & GP- $0.40 ; 1.75$ & 0.255 & 0.145 & 1.40 \\
\hline GP 04 & GP- $0.40 ; 2.00$ & 0.267 & 0.133 & 1.40 \\
\hline GP 05 & GP- $0.40 ; 2.50$ & 0.286 & 0.114 & 1.40 \\
\hline GP 06 & GP- $0.57 ; 0.50$ & 0.190 & 0.380 & 1.57 \\
\hline GP 07 & GP- $0.57 ; 1.00$ & 0.285 & 0.285 & 1.57 \\
\hline GP 08 & GP-0.57; 1.75 & 0.363 & 0.207 & 1.57 \\
\hline GP 09 & GP- $0.57 ; 2.00$ & 0.380 & 0.190 & 1.57 \\
\hline GP 10 & GP-0.57; 2.50 & 0.407 & 0.163 & 1.57 \\
\hline
\end{tabular}

The cubical samples were sealed immediately after casting in oven bags to minimize the effects of initial surface evaporation. The sealed specimens were subjected to oven conditioning, at $60^{\circ} \mathrm{C}$ for $24 \mathrm{~h}$ in a WEISS WVC Series Temperature and Climatic Test Chamber. Once hardened, the cubes were removed from the molds, re-sealed and placed in the oven. The initial compressive strengths were tested after $24 \mathrm{~h}$ of curing and residual strengths were tested after exposure to $400{ }^{\circ} \mathrm{C}$ and $800{ }^{\circ} \mathrm{C}$ using the process defined in Section 3.2.

\subsubsection{Reactive Powder-Based Concrete (RPC)}

Type 1 Bastion General Purpose cement, supplied by DINGO Cement Pty Ltd., Burwood, Australia, complying with AS 3972-2010-General purpose and blended cements [35] and silica fumes, supplied from Master Builders Solutions by BASF, Australia, were used as the binder materials. The silica fumes were grey in color, comprised of very fine, spherical particles and met the requirements of AS/NZS 3582.3:2016-Supplementary cementitious materials. Part 3-Amorphous silica [36]. An XRF analyzer was used to determine the chemical compositions of silica fumes and the relevant data were supplied by the manufacturer (Table 3). Processed $50 \mathrm{~N}$ silica sand, with a maximum particle size of $600 \mu \mathrm{m}$, obtained from North Stradbroke Island, Australia and silica flour, which was white in color and supplied from Unimin Australia Ltd., Nyora, Australia, were used as the aggregate particles.

Table 3. Chemical composition of silica fumes.

\begin{tabular}{cc}
\hline Compound & Component (wt. \%) \\
\hline $\mathrm{Al}_{2} \mathrm{O}_{3}$ & 0.70 \\
$\mathrm{SiO}_{2}$ & 95.5 \\
$\mathrm{CaO}$ & 0.40 \\
$\mathrm{Fe}_{2} \mathrm{O}_{3}$ & 0.30 \\
$\mathrm{~K}_{2} \mathrm{O}$ & 1.00 \\
$\mathrm{MgO}$ & 0.50 \\
$\mathrm{Na}_{2} \mathrm{O}$ & 0.40 \\
Other & 1.20 \\
\hline
\end{tabular}

With regard to the liquid components used in the RPC mixtures, Glenium 51 high range water reducer was the superplasticiser (SP) used which was based on the work reported by Menefy [6], along with normal tap water. Three RPC mix designs were initially selected according to literature precedents (see in Table 4). However, the initial mixing processes resulted in poor workability-hence, mix design combinations were refined (Table 4). An excess amount of water was added to the aggregate particles in order to achieve saturated surface dry (SSD) conditions. 
Table 4. Mix combinations of RPC, including refined combinations.

\begin{tabular}{ccccc}
\hline Sample ID & RPC 01-a & RPC 01-b & RPC 02 & RPC 03 \\
\hline Amount needed $\left(\mathrm{m}^{3}\right)$ & 1.0 & 1.0 & 1.0 & 1.0 \\
Total weight initial $(\mathrm{kg})$ & 2212 & 2212 & 2398 & 2249 \\
Cement $(\mathrm{kg})$ & 680 & 680 & 955 & 830 \\
Silica fumes $(\mathrm{kg})$ & 204 & 204 & 229 & 291 \\
Silica flour $(\mathrm{kg})$ & 204 & 204 & 10.0 & 488 \\
Silica sand $(\mathrm{kg})$ & 974.0 & 974.0 & 1051 & 489.0 \\
SP $(\mathrm{mL})$ & 44,000 & 44,000 & 13,000 & 55,000 \\
Water $(\mathrm{kg})$ & 150 & 150 & 153 & 151 \\
Initial w/c & 0.22 & 0.22 & 0.16 & 0.18 \\
Absorption by total sand \% & 1.0 & 1.0 & 1.0 & 1.0 \\
Added water for absorption $(\mathrm{kg})$ & 11.7 & 11.7 & 10.6 & 10.6 \\
Added superplasticiser $(\mathrm{mL})$ & 0.0 & 2.0 & 16 & 0.0 \\
Added water $(\mathrm{kg})$ & 0.0 & 0.0 & 0.0 & 0.0 \\
Final w/c & 0.22 & 0.22 & 0.16 & 0.18 \\
Super of cement + cume \% & 4.9 & 4.9 & 1.0 & 4.9 \\
Final weight (kg) & 2224 & 2224 & 2409 & 2259 \\
Original reference & {$[37]$} & {$[37]$} & {$[2]$} & {$[27]$} \\
\hline
\end{tabular}

Mixing times and the rate of mixing were reported to be the crucial parameters, especially, in achieving high performances. Several reports have described the mixing processes, where the dry materials that are needed to be initially machine mixed for a period of 3-5 min at low speeds, after which the liquids are required to be added and then machine mixed for about 5-10 min. However, these time periods are known to vary among the various studies [27,38-42]. In addition, high energy machine mixers at shorter mixing times are proved to provide workable mixtures $[6,43]$.

In the present study, the mixing procedure of RPC formulations were very similar to the one reported by Menefy [6], who has also referred to a typical staged- mixing approach as previously published [44]. Here, the dry materials (cement, silica fumes, silica sand and silica flour) were measured and machine-blended using a Breville mixer for $2 \mathrm{~min}$ at a working speed of $50 \mathrm{rpm}$ until the dry materials reached homogeneous consistency. Subsequently, the super plasticizer (SP) and water were pre-mixed and added into dry mix. This was then machine-mixed for $30 \mathrm{~min}$ at $85 \mathrm{rpm}$ until a workable mixture was obtained. A delayed addition of superplasticizer was effected for RPC 01-a and RPC 02 mixtures with a view to obtaining a SP to cementitious material content of approximately $5 \mathrm{wt}$. \%.

Subsequently, $25 \mathrm{~mm}^{3}$ cubes were casted. After hardening, the RPC cubes were subjected to water curing at two different temperatures, $20^{\circ} \mathrm{C}$ and at $75^{\circ} \mathrm{C}$, in a temperaturecontrolled water bath. This conditioning procedure was done in order to test the effects of ambient-temperature water-curing on the compressive strength of the samples that were conditioned for 7 days. Such samples were labelled RPC 01-a.

\subsubsection{Reactive Powder Geopolymer Concrete (RPGC)}

The reactive powder geopolymer concrete (RPGC) was casted using a mix of GP and RPC. A total of four RPGC mixes were casted with zero utilization of cement. The starting ingredients, such as, solid materials (FA, silica fumes, silica sand and silica flour) and liquid components (alkaline solution, SP and water) used to cast RPGC specimens, were the same as those used to cast GP pastes and RPC test samples. The corresponding mix design specifications are given in Table 5.

During mixing of RPCG, dry materials were machine mixed using a Breville mixer until homogeneity was reached (ca. $2 \mathrm{~min}$ at $50 \mathrm{rpm}$ ). The liquid solution (sodium hydroxide, sodium silicate and water) were premixed for $1 \mathrm{~min}$ and added with the dry ingredients. The resulting formulation was machine mixed for a further $2 \mathrm{~min}$ at $50 \mathrm{rpm}$ and then for $3 \mathrm{~min}$ at $85 \mathrm{rpm}$. 
Table 5. Mix Design—RPGC Trial and Error.

\begin{tabular}{ccccc}
\hline Mix Components & $\begin{array}{c}\text { RPC01 + } \\
\text { Gladstone } \\
\text { GP-0.4/2.5 } \\
\text { RPGC 01 }\end{array}$ & $\begin{array}{c}\text { RPC02 }+ \\
\text { Gladstone } \\
\text { GP-0.4/2.5 } \\
\text { RPGC 02 }\end{array}$ & $\begin{array}{c}\text { RPC01 + } \\
\text { Gladstone } \\
\text { GP-0.57/2.5 } \\
\text { RPGC 03 }\end{array}$ & $\begin{array}{c}\text { RPC02 }+ \\
\text { Gladstone } \\
\text { GP-0.57/2.5 } \\
\text { RPGC 04 }\end{array}$ \\
\hline Volume needed $\left(\mathrm{mm}^{3}\right)$ & 1.00 & 1.00 & 1.00 & 1.00 \\
GP cement $\left(\mathrm{kg} / \mathrm{m}^{3}\right)$ & - & - & - & - \\
Fly ash $(\mathrm{kg})$ & 680 & 955 & 680 & 955 \\
Silica fume $\left(\mathrm{kg} / \mathrm{m}^{3}\right)$ & 204 & 229 & 204 & 229 \\
Silica flour $200 \mathrm{G}\left(\mathrm{kg} / \mathrm{m}^{3}\right)$ & 204 & 10.0 & 204 & 10.0 \\
Silica sand $50 \mathrm{~N}\left(\mathrm{~kg} / \mathrm{m}^{3}\right)$ & 974 & 1051 & 974 & 1051 \\
Alkaline solution $(\mathrm{kg})$ & 272 & 382 & 388 & 544 \\
8 M NaOH $(\mathrm{kg})$ & 77.7 & 109 & 111 & 156 \\
Sodium silicate grade D $(\mathrm{kg})$ & 194 & 273 & 277 & 389 \\
SP $\left(\mathrm{L} / \mathrm{m}^{3}\right)$ & - & - & - & - \\
Water $\left(\mathrm{kg} / \mathrm{m}^{3}\right)$ & - & - & - & - \\
Added water due to absorption $(\mathrm{kg})$ & 11.7 & 10.6 & 11.7 & 10.6 \\
Added water due to workability $(\mathrm{kg})$ & - & - & - & - \\
Alkaline solution/fly ash ratio & 0.40 & 0.40 & 0.57 & 0.57 \\
Na SiO $_{3} / \mathrm{NaOH}$ & 2.50 & 2.50 & 2.50 & 2.50 \\
Aggregate/binder ratio & 2.03 & 1.35 & 2.03 & 1.35 \\
Total weight $(\mathrm{kg})$ & 2334 & 2627 & 2450 & 2789 \\
\hline
\end{tabular}

Following on from above, $25 \mathrm{~mm}^{3}$ RPGC specimens were casted. The curing conditioning procedure for RPGC was similar to GP paste specimens, where sealed cubes were subjected to dry oven curing at $60^{\circ} \mathrm{C}$ for $24 \mathrm{~h}$ in a WEISS WVC Series Temperature and Climatic Test Chamber. Subsequently, initial strength and residual strength testing was conducted.

\subsection{Exposure to Elevated Temperatures (Up to 400 , or $800^{\circ} \mathrm{C}$ )}

All samples were subjected to the same levels of exposure to the elevated temperatures (up to 400 , or $800^{\circ} \mathrm{C}$, as the case may be). During the exposure, heating was provided at a steady rate of $10{ }^{\circ} \mathrm{C} / \mathrm{min}$, up to the target temperatures, using a muffle furnace. The samples were held at the target temperature for a period of one hour, in order to ensure that the entire sample has obtained thermal equilibrium, i.e., a uniform temperature throughout the sample. The samples were then allowed to cool naturally to room temperature (ca. $25^{\circ} \mathrm{C}$ ), before they were tested for compressive strength. It is to be noted here that testing of specimens for residual compressive strength after they had been cooled down generally characterizes the lower bound strength values, as compared to the stressed residual test, where samples are tested whilst they are at elevated temperatures $[45,46]$.

\subsection{Testing Procedures}

The density measurements on test samples were recorded in accordance with $A S$ 1012.5:2014-Determination of mass per unit volume of freshly mixed concrete [47] and the workability was measured using a flow table apparatus, in accordance with ASTM C230/230M08-Standard Specification for Flow Table for Use in Tests of Hydraulic Cement [48]. The compressive strength testing was conducted in accordance with AS 1012.9.2014-Methods of testing concrete Method 9: Compressive strength tests—Concrete, mortar and grout specimens [49] using a $100 \mathrm{kN}$ Instron 1195 testing machine, at a loading rate of $20 \pm 2 \mathrm{MPa} / \mathrm{min}$. The cubical specimens were tested for initial compressive strength at $24 \mathrm{~h}$ after casting. No samples were subjected to a rest period, which meant that all samples were assumed to be immediately cured after casting. The measurements were done in triplicate and the average values are quoted. The mass loss for each test sample was measured using two methods: by using a balance and through thermo-gravimetric (TGA) runs. In the first method, cube samples were accurately weighed in an electronic balance before and after exposure to elevated temperature levels from which the difference in weights were calculated. In the 
second method, the Mettler Toledo TGA was used to determine the loss of mass. Powdered samples (obtained passing through the $0.425 \mu \mathrm{m}$ (ca. $20 \mathrm{mg}$ ) sieve were placed in silica crucibles and subjected to a constant heating rate of $10{ }^{\circ} \mathrm{C} / \mathrm{min}$ up to $800{ }^{\circ} \mathrm{C}$, under a nitrogen atmosphere and the mass loss of the samples (in wt. \%) were recorded with increasing temperatures (from 30 to $800^{\circ} \mathrm{C}$ ).

\section{Results and Discussion}

It is relevant to note here that the various empirical parameters, such as density, workability, compressive strengths and mass losses, obtained were averaged over triplicate measurements as the spread of values were quite acceptable given the nature of specific measurements in question. Furthermore, the standard deviations in the case of residual strength recordings are shown in the corresponding plots.

\subsection{Slump Flow Characteristics of the Mixtures}

The workability of fresh admixtures is an important factor to assess and evaluate the overall performance of concretes. Any given mix design is expected to maintain its fluid nature to enable mixing, transportation, placement and finishing procedures. The GP pastes in present study exhibited excellent workability parameters, which was expected as the mix matrix comprised of very fine and spherical shaped particles which are bestowed with a smooth flow character. The slump flow of GP 01-05 was lower than for GP 06-10, except for GP 07; this can be attributed to the higher alkaline solution to FA ratio of the latter half of the mixtures. The higher this ratio implies a higher fluid content in the mixture which produce a more liquid paste (see the results given in Table 6).

Table 6. Workability results for GP paste mixtures.

\begin{tabular}{cccc}
\hline Sample ID & $\mathbf{d 1} \mathbf{( m m )}$ & $\mathbf{d 2} \mathbf{( m m )}$ & Slump Flow $(\mathbf{m m})$ \\
\hline GP 01 & 300 & 300 & 300.0 \\
GP 02 & 300 & 305 & 302.5 \\
GP 03 & 315 & 310 & 312.5 \\
GP 04 & 300 & 300 & 300.0 \\
GP 05 & 290 & 300 & 295.0 \\
GP 06 & 305 & 310 & 307.5 \\
GP 07 & 280 & 280 & 280.0 \\
GP 08 & 310 & 320 & 315.0 \\
GP 09 & 330 & 340 & 335.0 \\
GP 10 & 320 & 330 & 325.0 \\
Minimum & 280 & 280 & 280.0 \\
Maximum & 330 & 340 & 335.0 \\
\hline
\end{tabular}

The Slump Flow results for RPC mixes are given in Table 7. Compared to the GP mixtures, RPC specimens displayed relatively low workability attributes, with a minimum slump flow of $111.0 \mathrm{~mm}$ and maximum of $132.5 \mathrm{~mm}$. This condition can be expected owing to the inclusion of aggregate particles which can increase the friction among the constituents and hence result in a decreased flow characteristics. Moreover, the RPC mixtures were observed to be denser compared to the GP pastes, which further reduces the workability characteristics of the mixture. The Flow Table results obtained in this study were found to be lower than the ASTM C230 standard requirement, which is $190 \mathrm{~mm}-250 \mathrm{~mm}$ after 20 drops. According to Gowripalan and Watters [37], this flow can be achieved with a mixing time of about $40 \mathrm{~min}$ at laboratory conditions.

The RPGC mixtures recorded a higher slump flow compared to RPC mixes, which could be due to the finer and spherical nature of the FA and this in turn can be assumed to improve the fluidity and workability conditions of the former. In contrast, RPGC formulations were appeared to be more viscous compared to GP paste mixes, thus recording poorer flow readings which could be due to the inclusion on aggregate particles which effectively could thicken the mixture, thus reducing the workability conditions. In addition, 
it can be noted that the flow-ability of RPGC 01 and 02 are much lower than RPGC 03 and 04 . This can be attributed to the value of the alkaline solution to FA ratio of the latter two mixtures (0.57), as compared to the former two mixtures (0.4), thus producing a more workable mix. The slump flow results are given in Table 8 .

Table 7. Workability results RPC mixtures.

\begin{tabular}{cccc}
\hline Sample ID & $\mathbf{d 1} \mathbf{( m m )}$ & $\mathbf{d 2}(\mathbf{m m})$ & Slump Flow $(\mathbf{m m})$ \\
\hline RPC 01-a & 130 & 135 & 132.5 \\
RPC 01-b & 120 & 120 & 120.0 \\
RPC 02 & 110 & 112 & 111.0 \\
Minimum & 110 & 112 & 111.0 \\
Maximum & 130 & 135 & 132.5 \\
\hline
\end{tabular}

Table 8. Workability results RPGC mixtures.

\begin{tabular}{cccc}
\hline Sample ID & d1 $\mathbf{( m m )}$ & $\mathbf{d 2} \mathbf{( m m )}$ & Slump Flow $(\mathbf{m m})$ \\
\hline RPGC 01 & 190 & 185 & 187.5 \\
RPGC 02 & 223 & 225 & 224.0 \\
RPGC 03 & 254 & 250 & 252.0 \\
RPGC 04 & 250 & 250 & 250.0 \\
Minimum & 190 & 185 & 187.5 \\
Maximum & 254 & 250 & 252.0 \\
\hline
\end{tabular}

\subsection{Density Measurements}

The values of density of the RPC mixtures were much higher than that of both GP and RPGC mixtures, with the highest reading of $2752 \mathrm{~kg} / \mathrm{m}^{3}$ recorded for RPC 01-b (Table 9). This can be expected as RPC is an ultra-high strength concrete, having very fine particles which provide a highly dense microstructure. The densest GP paste mix turned out to be GP 10 , with a density of $2396 \mathrm{~kg} / \mathrm{m}^{3}$ (Table 10). The RPGC mixtures, on the other hand, displayed a maximum density of $2245 \mathrm{~kg} / \mathrm{m}^{3}$ (for RPGC 01) and a minimum of $2120 \mathrm{~kg} / \mathrm{m}^{3}$ (for RPGC 04) (Table 11).

Table 9. Density results of RPC mixtures.

\begin{tabular}{ccc}
\hline Sample ID & Mass $\mathbf{( k g )}$ & Density $\mathbf{( k g / \mathbf { m } ^ { 3 } )}$ \\
\hline RPC 01-a & 0.2546 & 2546 \\
RPC 01-b & 0.2752 & 2752 \\
RPC 02 & 0.2715 & 2715 \\
\hline
\end{tabular}

Table 10. Density results of GP paste mixtures.

\begin{tabular}{|c|c|c|}
\hline Sample ID & Mass (kg) & Density $\left(\mathrm{kg} / \mathrm{m}^{3}\right)$ \\
\hline GP 01 & 0.2189 & 2189 \\
\hline GP 02 & 0.2272 & 2272 \\
\hline GP 03 & 0.2154 & 2154 \\
\hline GP 04 & 0.2335 & 2335 \\
\hline GP 05 & 0.2364 & 2364 \\
\hline GP 06 & 0.2203 & 2203 \\
\hline GP 07 & 0.2298 & 2298 \\
\hline GP 08 & 0.2308 & 2308 \\
\hline GP 09 & 0.2371 & 2371 \\
\hline GP 10 & 0.2396 & 2396 \\
\hline
\end{tabular}


Table 11. Density results of RPGC mixtures.

\begin{tabular}{ccc}
\hline Sample ID & Mass $\mathbf{( k g )}$ & Density $\mathbf{( k g / \mathbf { m } ^ { 3 } )}$ \\
\hline RPCG 01 & 0.2245 & 2245 \\
RPCG 02 & 0.2193 & 2193 \\
RPCG 03 & 0.2145 & 2145 \\
RPCG 04 & 0.2120 & 2120 \\
\hline
\end{tabular}

\subsection{Evaluations of Initial and Residual Strengths}

When considering the initial compressive strengths of GP specimens, majority of specimens having a lower alkaline solution to FA ratio (0.4) achieved higher initial strengths, when the $\mathrm{Na}_{2} \mathrm{SiO}_{3} / \mathrm{NaOH}$ ratios were kept constant. This could probably be due to the dense microstructure brought about from using a lower alkaline solution to FA ratio, which could result in fewer pores and hence higher internal strengths. In addition, when the alkaline solution to FA ratio was kept constant, the initial strength of the specimens were found to increase gradually as the $\mathrm{Na}_{2} \mathrm{SiO}_{3} / \mathrm{NaOH}$ ratios increased, which could be attributed to the inclusion of more sodium silicate, which in turn can enhance the geopolymerization reaction, thus resulting in higher strengths (Figure 2).

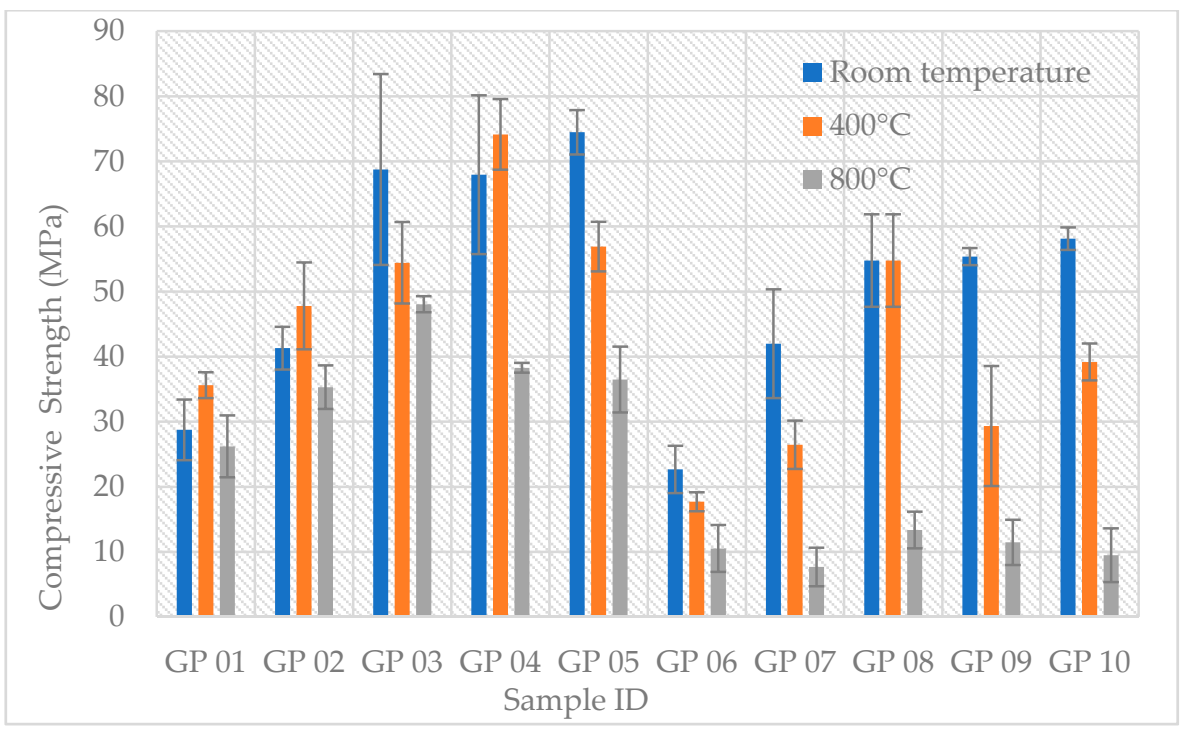

Figure 2. A plot of initial and residual compressive strengths of GP specimens.

After exposure to elevated temperature levels of $800^{\circ} \mathrm{C}$, majority of the GP specimens were found to be still intact with only mild cracking. Furthermore, no cracking was observed in GP $01-05$ specimens after being exposed to both $400{ }^{\circ} \mathrm{C}$ and $800{ }^{\circ} \mathrm{C}$ and mild cracking in the latter set of samples (i.e., GP 06-10), that too only after being exposed to $800{ }^{\circ} \mathrm{C}$. Owing to the high initial strengths and thermal performance of GP 05 and GP 10 , they were explored for further mix designs leading to the production of RPGC specimens.

When considering the initial strength developments of RPC specimens, conditioning was found to be a highly influential factor, where specimens conditioned at $25^{\circ} \mathrm{C}$ recorded much lower 7-day-strength readings compared to the specimens cast using the same mix design, but conditioned at $75^{\circ} \mathrm{C}$. The tabulated and associated graphical representation of, data are presented in Table 12 and Figure 3, respectively. Similar finding were reported previously [6,50], where it was also stated that a relatively lower percentage of calciumsilicate-hydrate (C-S-H) gels were produced, when an insufficient supply of heated water was provided, which was assumed to create a weaker microstructural matrix within RPC specimens. A previous report also showed that when RPC was water cured under room temperature, the pozzolanic activity was found to be slower, as heated water curing has the ability to rapidly increase the pozzolonic reaction of the silica fumes and increase the 
amounts of hydrated compounds occurring through the formation of secondary hydrated products. This, in turn can result in an increased extent of bonding between the cement paste and the aggregate particles, thus enhancing the internal strength. In addition, the formation of ettringite can hinder the rate of hydration thus, reduces the rate of strength development [42]. Moreover, a continuous supply of moisture can result in a higher consumption of portlandites, which can further lead to a higher degree of hydrated products. These hydrated products could act as an inert filler material which could in turn fill the voids and gel pores within the matrix. This could ultimately a lead to denser microstructure with a better interlocking structure and fewer capillary pores- similar findings were reported previously $[6,42,51]$.

Table 12. Average compressive strengths of RPC cubes.

\begin{tabular}{cc}
\hline Sample ID & Average Initial Compressive Strength (MPa) \\
\hline RPC 01-a $\left(25^{\circ} \mathrm{C}\right)$ & 86.0 \\
RPC 01-a $\left(75^{\circ} \mathrm{C}\right)$ & 141 \\
RPC $01-\mathrm{b}\left(75^{\circ} \mathrm{C}\right)$ & 95.1 \\
$\operatorname{RPC~} 02\left(75^{\circ} \mathrm{C}\right)$ & 108 \\
\hline
\end{tabular}

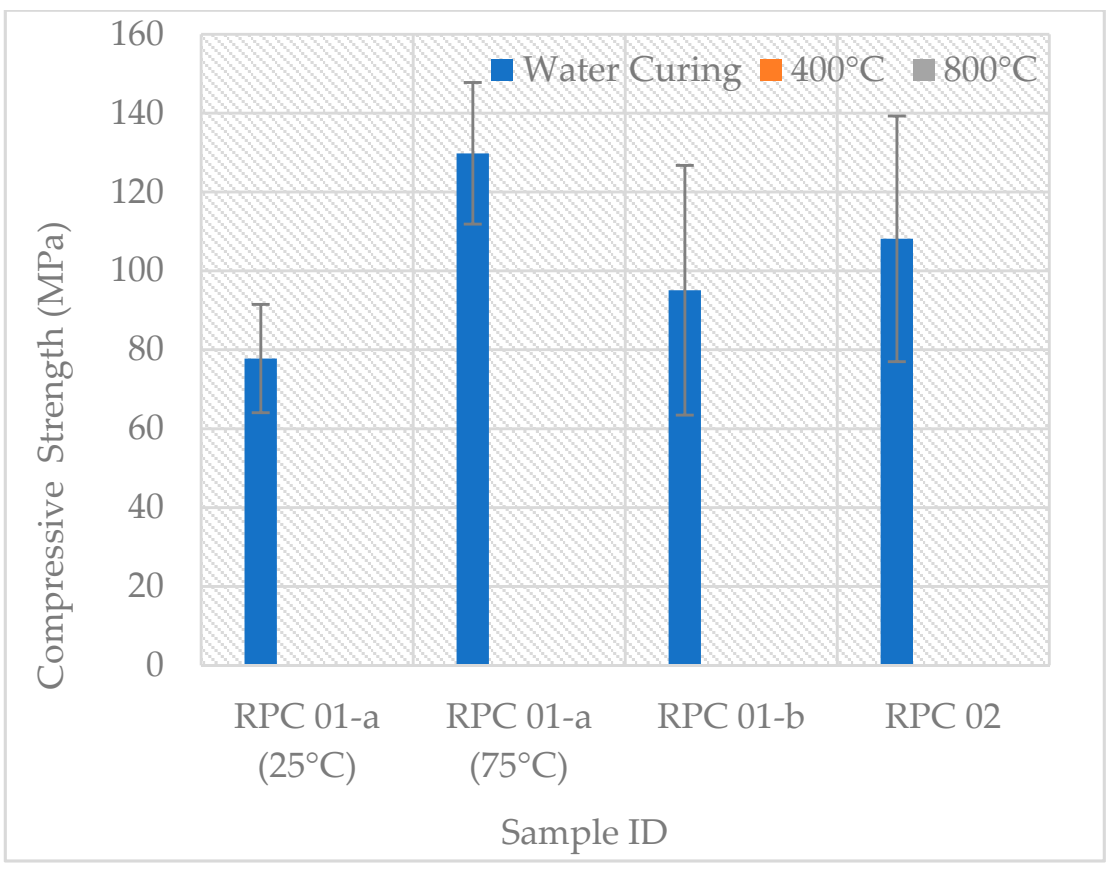

Figure 3. A plot of average initial compressive strengths of RPC specimens.

Regardless of the very high initial performances, the RPC specimens exhibited completely different thermal performances. These samples displayed explosive spalling phenomenon when the furnace temperature reached approximately $360^{\circ} \mathrm{C}$; hence no residual strength results could be measured. The occurrence of explosive spalling in the present study can be attributed to the formation of dense microstructures which in turn could limit the release of the internal pressure build-up during heating. Concomitantly, the occurrence of thermal gradients between the outside and the inside of the concrete could give rise to associated thermal stresses and once these stresses exceed the tensile strength, spalling can be expected to occur. Similar reports on the poor thermal capabilities of RPC have been presented elsewhere [52-54]. Figure 4 shows the RPC specimens before and after exposure to elevated temperatures. 


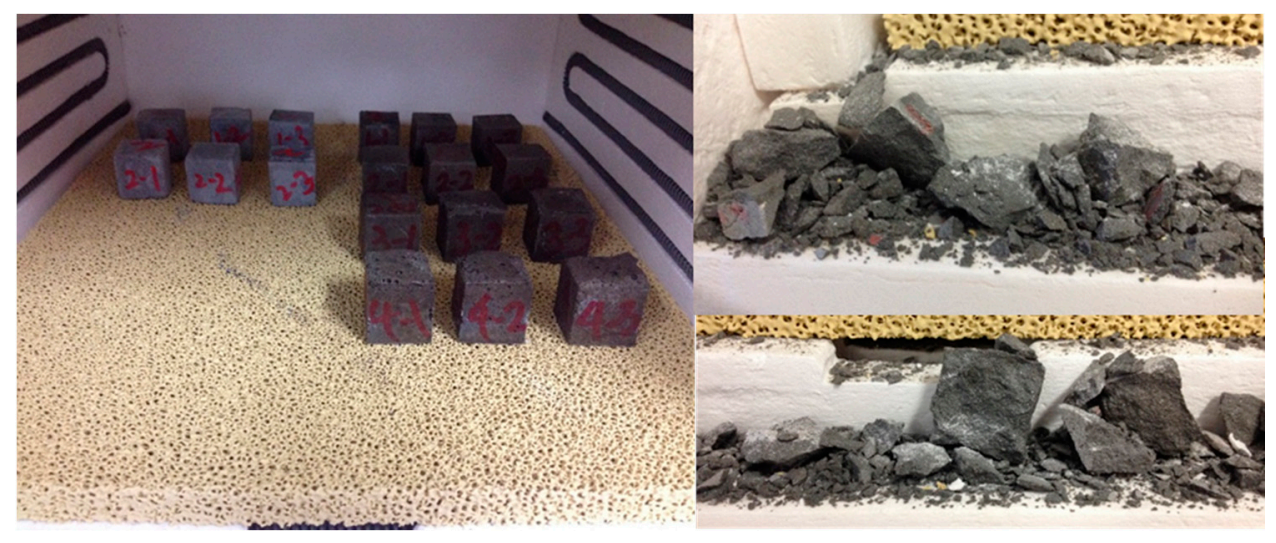

Figure 4. RPC specimens before (left) and after (right) exposure to elevated temperatures.

The RPGC 01 specimens, which was a combination of GP 05 and RPC 01-a, performed the best in terms of initial compressive and residual strengths, with an initial strength of approximately $76 \mathrm{MPa}$ and residual strengths of approximately $61 \mathrm{MPa}$ and $51 \mathrm{MPa}$ at $400{ }^{\circ} \mathrm{C}$ and $800{ }^{\circ} \mathrm{C}$, respectively (Table 13). It was also noted that at a lower alkaline solution to FA ratio and a high silica flour content, improved strengths, both initial and residual, can be achieved. Thus the low alkaline solution to FA ratio could provide a denser microstructure with reduced porosity and hence can increase the bondage between the paste and the aggregate particles. The high flour content can be advantageous as the silica content can increase the pozzolanic reaction and can also act as a filler which can further increase internal strength. Similar observations were previously reported [55].

Table 13. Average compressive strengths of RPGC cubes.

\begin{tabular}{cccccc}
\hline Sample ID & $\begin{array}{c}\text { Room } \\
\text { Temperature }\end{array}$ & $\mathbf{4 0 0}{ }^{\circ} \mathbf{C}$ & $\mathbf{8 0 0}{ }^{\circ} \mathbf{C}$ & $\begin{array}{c}\text { Thermal } \\
\text { Cracking } \mathbf{4 0 0}{ }^{\circ} \mathbf{C}\end{array}$ & $\begin{array}{c}\text { Thermal } \\
\text { Cracking } \mathbf{8 0 0}\end{array}$ \\
\hline RPCG 01 & 76.25 & 60.58 & 50.52 & No & No \\
RPCG 02 & 64.54 & 44.43 & 30.58 & No & No \\
RPCG 03 & 38.59 & 21.67 & 14.90 & No & Yes \\
RPCG 04 & 19.55 & 18.34 & 14.42 & No & No \\
Minimum & 19.55 & 18.34 & 14.42 & N/A & N/A \\
Maximum & 76.25 & 60.58 & 50.52 & N/A & N/A \\
\hline
\end{tabular}

The RPGC specimens were observed to behave exceptionally well after exposure to a high temperature; for instance, no cracking was evident from any of the specimens after exposure to $400{ }^{\circ} \mathrm{C}$. Additionally, apart from RPGC 03 specimens which displayed slight cracking, no other specimens displayed any cracking even after being exposed to $800^{\circ} \mathrm{C}$. The RPGC specimens produced strengths within the range of approximately $18-61 \mathrm{MPa}$ at $400{ }^{\circ} \mathrm{C}$ and approximately $14-51 \mathrm{MPa}$ at $800{ }^{\circ} \mathrm{C}$, with maximum strength drops of approximately $20 \%$ and $33 \%$ at $400{ }^{\circ} \mathrm{C}$ and $800{ }^{\circ} \mathrm{C}$, respectively. In particular, RPGC 04 proved to be the weakest mixture producing the lowest initial and residual strength readings. Figure 5 shows a graphical representation of the strengths of RPGC specimens.

\subsection{Mass Loss Measurements}

Table 14 shows the percentage mass loss values from TGA (powdered samples) and $25 \mathrm{~mm}$ cubes measured by using a balance for GP paste specimens. The average values of the mass loss measurements using the balance were approximately $17 \%$ for samples after being exposed to temperatures of both $400{ }^{\circ} \mathrm{C}$ and $800^{\circ} \mathrm{C}$. The specimens that were subjected to the thermo-gravimetric analysis (TGA showed relatively much lesser losses, with averages of approximately $7.5 \%$ and $9.4 \%$ for $400{ }^{\circ} \mathrm{C}$ and $800{ }^{\circ} \mathrm{C}$ exposure, respectively. This difference in mass loss percentages could be due to the severe thermal cracking, which could have caused minor corner spalling to occur in the cube specimens, thus resulting in 
higher losses. However, it may be noted here that mass measurements taken on bulk samples (i.e., cubes) can be considered to be more reliable than the corresponding ones obtained through TGA runs as inhomogeneity of the samples can be considered to be amplified in mg scales (i.e., in the case of thermograms obtained from the TGA runs). When considering the high initial rate of mass loss can be attributed to the evaporation of physically bound (free) moisture, after which the rate reduces and somewhat stabilizes [25,56-59]. The continued loss in mass after the initial steep drop, can be due to the loss of chemically bound water and in part resulting from the decomposition of $\mathrm{CaCO}_{3}\left(\mathrm{ca} .700\right.$ to $800^{\circ} \mathrm{C}$ ) within the concrete matrix [57].

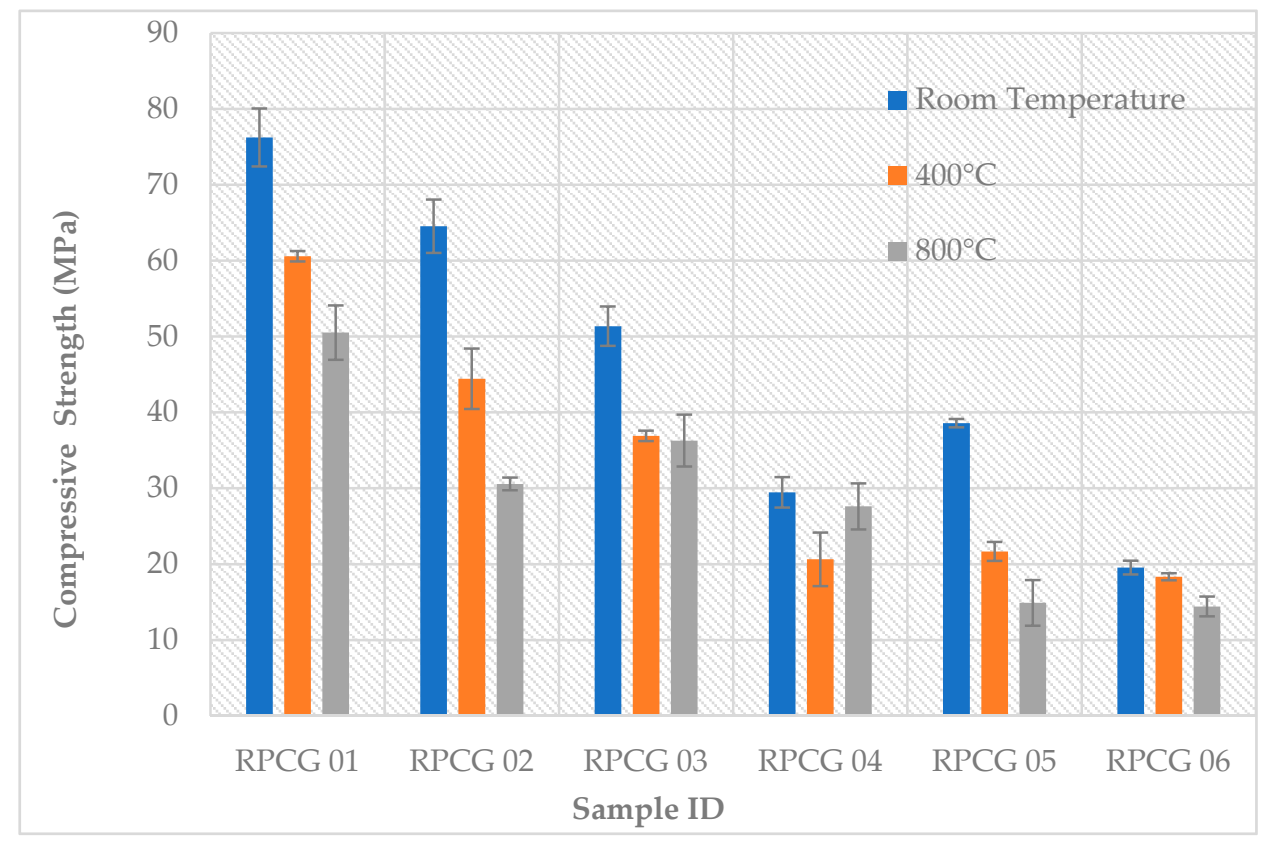

Figure 5. A plot of average initial and residual compressive strengths of RPGC specimens.

Table 14. Average compressive strengths of RPGC cubes.

\begin{tabular}{ccccc}
\hline & \multicolumn{2}{c}{ Mass Loss (wt. \%) from TGA } & \multicolumn{2}{c}{ Mass Loss (wt. \%) from Weighing } \\
Sample ID & $\mathbf{4 0 0}{ }^{\circ} \mathbf{C}$ & $\mathbf{8 0 0}{ }^{\circ} \mathbf{C}$ & $\mathbf{4 0 0}{ }^{\circ} \mathbf{C}$ & $\mathbf{8 0 0}{ }^{\circ} \mathbf{C}$ \\
\hline GP 01 & 6.47 & 8.45 & 14.10 & 15.88 \\
GP 02 & 6.59 & 8.09 & 14.61 & 15.34 \\
GP 03 & 7.16 & 8.73 & 14.08 & 14.86 \\
GP 04 & 6.66 & 7.78 & 15.09 & 15.37 \\
GP 05 & 6.73 & 7.84 & 15.08 & 15.79 \\
GP 06 & 7.89 & 10.56 & 22.39 & 21.68 \\
GP 07 & 8.66 & 11.76 & 20.33 & 20.99 \\
GP 08 & 8.36 & 10.69 & 19.27 & 19.52 \\
GP 09 & 8.64 & 10.22 & 19.66 & 19.31 \\
GP 10 & 7.89 & 9.65 & 19.75 & 20.04 \\
Minimum & 6.47 & 7.78 & 14.08 & 14.86 \\
Maximum & 8.66 & 11.76 & 22.39 & 21.68 \\
Average & 7.51 & 9.38 & 17.43 & 17.88 \\
\hline
\end{tabular}

The RPGC specimens recorded the lowest percentages in mass losses, from TGA runs and measurements using a balance, as compared to the GP paste specimens. This could be due to the higher percentage of solid particles (and hence lower water loadings) within the RPGC specimens as compared to the GP specimens. Hence, the overall loss of mass is potentially reduced as mass loss can be thought to arise mainly from the loss of moisture. In addition, among the RPGC specimens, RPGC 01 cube specimens recorded to be the densest (i.e., having a density value of $2245 \mathrm{~kg} / \mathrm{m}^{3}$ ). This effectively means that a lower 
percentage of moisture was available for evaporation at elevated temperature levels; hence, would result in lower mass losses. Similar assumptions were made in previous studies involving the testing of conventional and GP concretes [23,60]. Additionally, compared to OPC concretes which continue to have a consistent rate of mass loss up to $650^{\circ} \mathrm{C}$ due to the dehydration of $\mathrm{Ca}(\mathrm{OH})_{2}$, the RPGC specimens recorded a reduced rate of mass loss above a temperature of $400{ }^{\circ} \mathrm{C}$, which indicate that the RPGC specimens have a relatively higher storage capacity and thermal stability- these features could also help them maintain their structural integrity even at higher temperatures. Table 15 provides tabulated data of the percentage mass losses of the RPGC specimens.

Table 15. Percentage mass loss (TGA and Balance results)-RPGC.

\begin{tabular}{ccccc}
\hline & \multicolumn{2}{c}{ Mass Loss (wt. \%) from TGA } \\
$\mathbf{4 0 0}{ }^{\circ} \mathbf{C}$ & $\mathbf{8 0 0}{ }^{\circ} \mathbf{C}$ & \multicolumn{2}{c}{ Mass Loss (wt. \%) from Weighing } \\
$\mathbf{4 0 0}{ }^{\circ} \mathbf{C}$ & $\mathbf{8 0 0}{ }^{\circ} \mathbf{C}$ \\
\hline RPGC 01 & 3.06 & 3.97 & 6.750 & 5.600 \\
RPGC 02 & 3.75 & 4.81 & 8.060 & 8.070 \\
RPGC 03 & 5.00 & 5.86 & 9.000 & 9.030 \\
RPGC 04 & 5.95 & 6.64 & 11.23 & 11.32 \\
Minimum & 3.06 & 3.97 & 6.750 & 5.600 \\
Maximum & 5.95 & 6.64 & 11.23 & 11.32 \\
Average & 4.44 & 5.32 & 8.760 & 8.510 \\
\hline
\end{tabular}

In summary, the RPGC specimens tested after a conditioning period of $24 \mathrm{~h}$ at $60{ }^{\circ} \mathrm{C}$ displayed higher strength readings, with a highest initial strength value of approximately $76 \mathrm{MPa}$ for RPGC 01. This is somewhat similar to the initial strength reading recorded from GP 05 with an increase of about $2 \mathrm{MPa}$, with RPGC 01 being the higher of the two. In addition, RPGC 01 recorded the highest residual strength after being exposed to $800{ }^{\circ} \mathrm{C}$ compared to all the GP specimens.

\section{Conclusions}

This research was focused on investigating the performance of a novel material called reactive powder geopolymer concrete (RPGC). Class-F (low calcium) FA was used as the source material, which effectively eliminated the need to use ordinary Portland cement in the mix design. The RPGC formulations were a combination of the geopolymer (GP) paste and reactive powder concrete (RPC) mix designs, selected through a series of trial tests. Even though several studies have been reported on the performance of GPs and RPCs, the available literature on the mechanical properties and, most importantly, the fire performance of the combination of these two materials are scarce. The key finding from the present study can be summarized as follows:

- Generally, the RPC samples that were investigated in the present study produced low workability conditions as compared to the GP and RPGC samples.

- The RPGC specimens, on the other hand, displayed higher workability conditions. This can be due to the relatively smaller particle sizes of the FA used for the casting of RPGC samples, as compared to the cement in RPC ones.

- The slump flow values of the RPGC specimens were somewhat lower when compared to the corresponding values of the GP mixtures. This can be attributed to the inclusion of aggregate particles in the RPGC formulations. The RPC specimens that were conditioned at $75^{\circ} \mathrm{C}$ recorded higher compressive strengths compared to those conditioned at the ambient temperature. This can be assumed to arise from the formation of relatively denser microstructures, thus leading to a better cohesive bonding state.

- Furthermore, the RPC specimens were found to undergo explosive spalling, at an elevated temperature (ca. $360^{\circ} \mathrm{C}$ ), presumably owing to the built up of increased vapor pressure and higher thermal gradients.

- Unlike the RPC specimens, no explosive spalling conditions were apparent in the RPGC specimens, with no thermal cracking at $400{ }^{\circ} \mathrm{C}$ and only one of the specimens 
undergoing mild thermal cracking even at $800{ }^{\circ} \mathrm{C}$. This can be due to the higher levels of silicon in the FA compared to OPC.

- The RPGC specimens generally recorded lower percentage losses in mass compared to the GP specimens, which could be due to the reduced water loading in them.

Author Contributions: Conceptualization, M.G., S.F. and P.J.; methodology, M.G. and T.K.; validation, M.G., S.F., P.J. and T.K.; formal analysis, T.K.; investigation, M.G., S.F., P.J. and T.K.; resources, M.G.; data curation, M.G., S.F., P.J. and T.K.; writing-original draft preparation, M.G., P.J. and T.K.; writing-review and editing, P.J.; supervision, M.G., S.F. and P.J.; project administration, M.G., S.F. and P.J.; funding acquisition, M.G. All authors have read and agreed to the published version of the manuscript.

Funding: This research received no external funding.

Institutional Review Board Statement: Not applicable.

Informed Consent Statement: Not applicable.

Data Availability Statement: Data is contained within the current article.

Acknowledgments: The authors are grateful for the technical support provided by Lyndon Macindoe and Philip Dunn, Institute for Sustainable Industries and Liveable Cities.

Conflicts of Interest: The authors declare no conflict of interest.

\section{References}

1. Team, E. Reactive Powder Concrete; Purdue ECT Team, Purdue University: West Lafayette, Indiana, 2007.

2. Richard, P.; Cheyrezy, M.H. Reactive Powder Concretes with High Ductility and 200-800 MPa Compressive Strength. Spec. Publ. 1994, 144, 507-518.

3. Richard, P.; Cheyrezy, M. Composition of Reactive Powder Concretes. Cem. Concr. Res. 1995, 25, 1501-1511. [CrossRef]

4. Lee, M.-G.; Wang, Y.-C.; Chiu, C.-T. A Preliminary Study of Reactive Powder Concrete as a New Repair Material. Constr. Build. Mater. 2007, 21, 182-189. [CrossRef]

5. Chan, Y.-W.; Chu, S.-H. Effect of Silica Fume on Steel Fiber Bond Characteristics in Reactive Powder Concrete. Cem. Concr. Res. 2004, 34, 1167-1172. [CrossRef]

6. Menefy, L. Investigation of Reactive Powder Concrete and It's Damping Characteristics When Utilised in Beam Elements; Griffith University: Gold Coast, QLD, Australia, 2007.

7. Coppola, L.; Troli, R.; Borsoi, A.; Zaffaroni, P.; Collepardi, M. Influence of Superplasticizer Type on the Compressive Strength of RPM. In Proceedings of the Fifth CANMET/ACI International Conference on Superplasticizers and Other Chemical Admixtures in Concrete, Roma, Italy; ACI International: Farmington Hills, MI, USA, 1997.

8. Peng, G.-F.; Kang, Y.R.; Huang, Y.Z.; Liu, X.P.; Chen, Q. Experimental Research on Fire Resistance of Reactive Powder Concrete. Adv. Mater. Sci. Eng. 2012, 2012, 860303. [CrossRef]

9. Tian, K.P.; Ju, Y.; Liu, H.B.; Liu, J.H.; Wang, L.; Liu, P.; Zhao, X. Effects of Silica Fume Addition on the Spalling Phenomena of Reactive Powder Concrete. In Applied Mechanics and Materials. Trans. Tech. Publ. 2012, 174, 1090-1095.

10. So, H.-S.; Yi, J.B.; Khulgadai, J.; So, S.Y. Properties of Strength and Pore Structure of Reactive Powder Concrete Exposed to High Temperature. ACI Mater. J. 2014, 111, 335-346. [CrossRef]

11. Zheng, W.; Luo, B.; Wang, Y. Compressive and Tensile Properties of Reactive Powder Concrete with Steel Fibres at Elevated Temperatures. Constr. Build. Mater. 2013, 41, 844-851. [CrossRef]

12. Ju, Y.; Liu, H.; Tian, K.; Liu, J.; Wang, L.; Ge, Z. An Investigation on Micro Pore Structures and the Vapor Pressure Mechanism of Explosive Spalling of RPC Exposed to High Temperature. Sci. China Technol. Sci. 2013, 56, 458-470. [CrossRef]

13. Lloyd, N.; Rangan, V. Geopolymer Concrete with Fly Ash. In Proceedings of the Second International Conference on Sustainable Construction Materials and Technologies; UWM Center for By-Products Utilization: Milwaukee, WI, USA, 2010.

14. Davidovits, J. Synthesis of New High-Temperature Geopolymers for Reinforced Plastics/Composites, in SPE PACTFC 79, Society of Plastic Engineers; Brookfield Center: Fairfield County, CT, USA, 1979; pp. 151-154.

15. Davidovits, J. Geopolymers: Inorganic Polymeric New Materials. J. Therm. Anal. 1991, 37, 1633-1656. [CrossRef]

16. Lyon, R.E.; Balaguru, P.N.; Foden, A.; Sorathia, U.; Davidovits, J.; Davidovics, M. Fire-Resistant Aluminosilicate Composites. Fire Mater. 1997, 21, 67-73. [CrossRef]

17. Lee, W.K.W.; van Deventer, J.S.J. The Effect of Ionic Contaminants on the Early-Age Properties of Alkali-Activated Fly Ash-based Cements. Cem. Concr. Res. 2002, 32, 577-584. [CrossRef]

18. Wang, H.; Li, H.; Yan, F. Reduction in Wear of Metakaolinite-Based Geopolymer Composite through Filling of PTFE. Wear 2005, 258, 1562-1566. [CrossRef] 
19. Palomo, A.; Blanco-Varela, M.T.; Granizo, M.L.; Puertas, F.; Vazquez, T.; Grutzeck, M.W. Chemical Stability of Cementitious Materials Based on Metakaolin. Cem. Concr. Res. 1999, 29, 997-1004. [CrossRef]

20. Duxson, P.; Lukey, G.C.; van Deventer, J.S.J. Thermal Conductivity of Metakaolin Geopolymers Used as a First Approximation for Determining Gel Interconnectivity. Ind. Eng. Chem. Res. 2006, 45, 7781-7788. [CrossRef]

21. Shaikh, F. Effects of Alkali Solutions on Corrosion Durability of Geopolymer Concrete. Adv. Concr. Constr. 2014, 2, 109-123. [CrossRef]

22. Türkmen, İ; Karakoç, M.B.; Kantarcı, F.; Maraş, M.M.; Demirboğa, R. Fire Resistance of Geopolymer Concrete Produced from Elazı̆̆ Ferrochrome Slag. Fire Mater. 2016, 40, 836-847. [CrossRef]

23. Sarker, P.K.; Kelly, S.; Yao, Z. Effect of Fire Exposure on Cracking, Spalling and Residual Strength of Fly Ash Geopolymer Concrete. Mater. Des. 2014, 63, 584-592. [CrossRef]

24. Kong, D.L.; Sanjayan, J.G. Damage Behavior of Geopolymer Composites Exposed to Elevated Temperatures. Cem. Concr. Compos. 2008, 30, 986-991. [CrossRef]

25. Kong, D.L.Y.; Sanjayan, J.G. Effect of Elevated Temperatures on Geopolymer Paste, Mortar and Concrete. Cem. Concr. Res. 2010, 40, 334-339. [CrossRef]

26. Kong, D.; Sanjayan, J.; Sagoe-Crentsil, K. Comparative Performance of Geopolymers Made with Metakaolin and Fly Ash after Exposure to Elevated Temperatures. Cem. Concr. Res. 2007, 37, 1583-1589. [CrossRef]

27. Yazıcı, H.; Yardımcı, M.Y.; Aydın, S.; Karabulut, A.Ş. Mechanical Properties of Reactive Powder Concrete Containing Mineral Admixtures under Different Curing Regimes. Constr. Build. Mater. 2009, 23, 1223-1231. [CrossRef]

28. Yazıcı, H.; Yiğiter, H.; Karabulut, A.Ş.; Baradan, B. Utilization of Fly Ash and Ground Granulated Blast Furnace Slag as an Alternative Silica Source in Reactive Powder Concrete. Fuel 2008, 87, 2401-2407. [CrossRef]

29. Ng, T.S.; Voo, Y.L.; Foster, S.J. Sustainability with Ultra-High Performance and Geopolymer Concrete Construction. In Innovative Materials and Techniques in Concrete Construction; Springer: Dordrecht, The Netherlands, 2012; pp. 81-100.

30. ASTM C 618. Standard Specification for Coal Fly Ash and Raw or Calcined Natural Pozzolan for Use in Concrete; ASTM: West Conshohocke, PA, USA, 2012.

31. Brunauer, S.; Emmett, P.H.; Teller, E. Adsorption of Gases in Multimolecular Layers. J. Am. Chem. Soc. 1938, 60, 309-319. [CrossRef]

32. Pathan, S.M.; Aylmore, L.A.; Colmer, T.D. Properties of Several Fly Ash Materials in Relation to Use as Soil Amendments. J. Environ. Qual. 2003, 32, 687-693. [CrossRef]

33. Rangan, B.V. Fly Ash-Based Geopolymer Concrete. Indian Concr. J. 2006, 80, 35.

34. Hardjito, D.; Rangan, B.V. Development and Properties of Low Calcium Based Geopolymer Concrete; Curtin University of Technology: Perth, Australia, 2005.

35. Standard, A. General Purpose and Blended Cements; Standard Australian: Sydney, Australia, 2010.

36. Standard, A.N.Z. Supplementary Cementitious Materials. Part 3: Amorphous Silica; Standard Australian: Sydney, Australia, 2016.

37. Gowripalan, N.; Watters, R.; Gilbert, I.; Cavill, B. Reactive Powder Concrete (Ductal ${ }^{\circledR}$ ) for Precast Structural Concrete-Research and Development in Australia. In Proceedings of the 21st Biennial Conference of the CIA, Brisbane, Australia, 18-21 July 2003.

38. Yazıc1, H.; Deniz, E.; Baradan, B. The Effect of Autoclave Pressure, Temperature and Duration Time on Mechanical Properties of Reactive Powder Concrete. Constr. Build. Mater. 2013, 42, 53-63. [CrossRef]

39. Zdeb, T. An Analysis of the Steam Curing and Autoclaving Process Parameters for Reactive Powder Concretes. Constr. Build. Mater. 2017, 131, 758-766. [CrossRef]

40. Mostofinejad, D.; Nikoo, M.R.; Hosseini, S.A. Determination of Optimized Mix Design and Curing Conditions of Reactive Powder Concrete (RPC). Constr. Build. Mater. 2016, 123, 754-767. [CrossRef]

41. Helmi, M.; Hall, M.R.; Stevens, L.A.; Rigby, S.P. Effects of High-Pressure/Temperature Curing on Reactive Powder Concrete Microstructure Formation. Constr. Build. Mater. 2016, 105, 554-562. [CrossRef]

42. Hiremath, P.N.; Yaragal, S.C. Effect of Different Curing Regimes and Durations on Early Strength Development of Reactive Powder Concrete. Constr. Build. Mater. 2017, 154, 72-87. [CrossRef]

43. Ma, J.; Orgass, M.; Dehn, F.; Schmidt, D.; Tue, N.V. Comparative Investigations on Ultra-High Performance Concrete with and without Coarse Aggregates. In Proceedings of the International Symposium on Ultra High Performance Concrete, Kassel, Germany, 13-15 September 2004.

44. Bonneau, O.; Lachemi, M.; Dallaire, E.; Dugat, J.; Aitcin, P.C. Mechanical Properties and Durability of Two Industrial Reactive Powder Concretes. Mater. J. 1997, 94, 286-290.

45. Phan, L. Fire Performance of High-Strength Concrete: A Report of the State of-the-Art; Building and Fire Research Laboratory, National Institute of Standards and Technology: Gaithersburg, MD, USA, 1996.

46. Guerrieri, M.; Sanjayan, J.G. Behavior of Combined Fly Ash/Slag-Based Geopolymers When Exposed to High Temperatures. Fire Mater. 2010, 34, 163-175. [CrossRef]

47. Standard, A. Methods of Testing Concrete Method 5: Determination of Mass Per Unit Volume of Freshly Mixed Concrete; Standard Australian: Sydney, Australia, 2014.

48. ASTM C230/C 230M-03. Standard Specification for Flow Table for Use in Tests of Hydraulic Cement; ASTM: West Conshohocken, PA, USA, 2008. 
49. Standard, A. Methods of Testing Concrete. Method 9: Compressive Strength Tests—Concrete, Mortar and Grout Specimens; Standards Australia Limited: Sydney, Australia, 2014.

50. Khadiranaikar, R.; Muranal, S. Factors Affecting the Strength of Reactive Powder Concrete (RPC). Int. J. Civil. Engg. Tech. 2012, 3, 455-464.

51. Courtial, M.; de Noirfontaine, M.N.; Dunstetter, F.; Signes-Frehel, M.; Mounanga, P.; Cherkaoui, K.; Khelidj, A. Effect of Polycarboxylate and Crushed Quartz in UHPC: Microstructural Investigation. Constr. Build. Mater. 2013, 44, 699-705. [CrossRef]

52. Liu, H.; Li, K.L.; Ju, Y.; Wang, H.J.; Wang, J.B.; Tian, K.P.; Wei, S. Explosive Spalling of Steel Fiber Reinforced Reactive Powder Concrete Subject to High Temperature. Concrete 2010, 8, 6-8.

53. Ju, Y.; Liu, J.; Liu, H.; Tian, K.; Ge, Z. On the Thermal Spalling Mechanism of Reactive Powder Concrete Exposed to High Temperature: Numerical and experimental studies. Int. J. Heat Mass Transf. 2016, 98, 493-507. [CrossRef]

54. Ju, Y.; Liu, H.; Liu, J.; Tian, K.; Wei, S.; Hao, S. Investigation on Thermophysical Properties of Reactive Powder Concrete. Sci. China Technol. Sci. 2011, 54, 3382-3403. [CrossRef]

55. Morsy, M.; Alsayed, S.; Aqel, M. Effect of Elevated Temperature on Mechanical Properties and Microstructure of Silica Flour Concrete. Int. J. Civ. Environ. Eng. 2010, 10, 1-6.

56. Abdulkareem, O.A.; Al Bakri, A.M.; Kamarudin, H.; Nizar, I.K.; Ala'eddin, A.S. Effects of Elevated Temperatures on the Thermal Behavior and Mechanical Performance of Fly Ash Geopolymer Paste, Mortar and Lightweight Concrete. Constr. Build. Mater. 2014, 50, 377-387. [CrossRef]

57. Su, H.; Xu, J.; Ren, W. Mechanical Properties of Geopolymer Concrete Exposed to Dynamic Compression under Elevated Temperatures. Ceram. Int. 2016, 42, 3888-3898. [CrossRef]

58. Mane, S.; Jadhav, H. Investigation of Geopolymer Mortar and Concrete under High Temperature. Magnesium 2012, 2, 384-390.

59. Pan, Z.; Sanjayan, J.G.; Rangan, B.V. An Investigation of the Mechanisms for Strength Gain or Loss of Geopolymer Mortar after Exposure to Elevated Temperature. J. Mater. Sci. 2009, 44, 1873-1880. [CrossRef]

60. Mendes, A.; Sanjayan, J.; Collins, F. Phase Transformations and Mechanical Strength of OPC/Slag Pastes Submitted to High Temperatures. Mater. Struct. 2008, 41, 345-350. [CrossRef] 